\title{
Active Learning Through Student-Centered Activity in the Instruction of Islamic Education Teachers as An Implementation of The 21st Century Learning: A Case Study
}

Naquiah Nahar, Jima'ain Safar, Aminudin Hehsan, Muhammad Talhah Jima'ain@Ajmain, Juhazren Junaidi, Zulkiflee Haron, Mohd Fauzi Abu Hussin

To Link this Article: http://dx.doi.org/10.6007/IJARBSS/v11-i11/11586

DOI:10.6007/IJARBSS/v11-i11/11586

Received: 07 September 2021, Revised: 11 October 2021, Accepted: 23 October 2021

Published Online: 14 November 2021

In-Text Citation: (Nahar et al., 2021)

To Cite this Article: Nahar, N., Safar, J., Hehsan, A., Jima'ain@Ajmain, M. T., Junaidi, J., Haron, Z., \& Hussin, M. F. A. (2021). Active Learning Through Student-Centered Activity in the Instruction of Islamic Education Teachers as An Implementation of The 21st Century Learning: A Case Study. International Journal of Academic Research in Business and Social Sciences, 11(11), 936-950.

Copyright: (C) 2021 The Author(s)

Published by Human Resource Management Academic Research Society (www.hrmars.com) This article is published under the Creative Commons Attribution (CC BY 4.0) license. Anyone may reproduce, distribute, translate and create derivative works of this article (for both commercial and non-commercial purposes), subject to full attribution to the original publication and authors. The full terms of this license may be seen at: http://creativecommons.org/licences/by/4.0/legalcode

Vol. 11, No. 11, 2021, Pg. 936 - 950

Full Terms \& Conditions of access and use can be found at http://hrmars.com/index.php/pages/detail/publication-ethics 


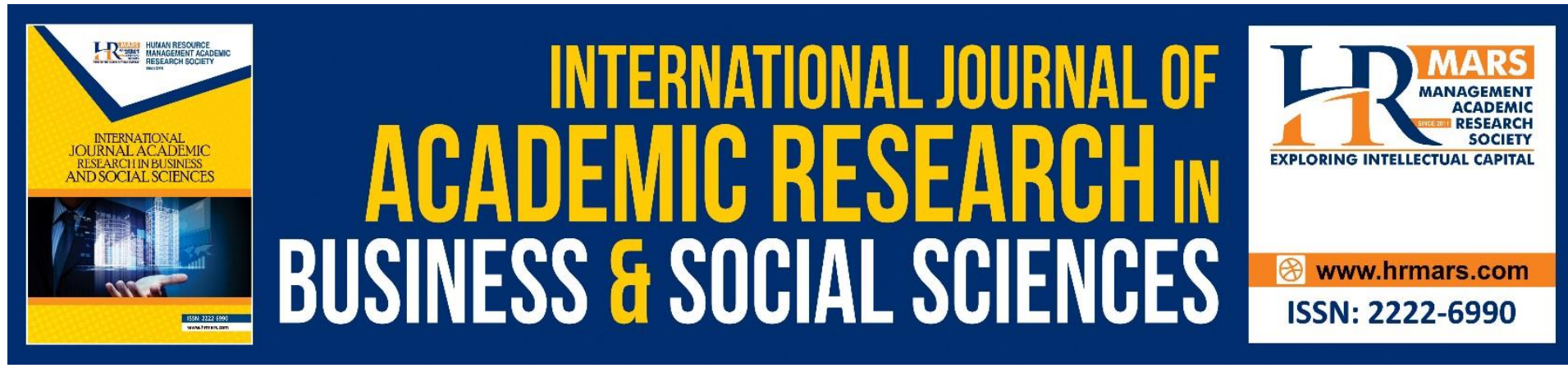

\title{
Active Learning Through Student-Centered Activity in the Instruction of Islamic Education Teachers as An Implementation of The 21st Century Learning: A Case Study
}

\author{
Naquiah Nahara, Jima'ain Safar ${ }^{b}$, Aminudin Hehsanc, \\ Muhammad Talhah Jima'ain@Ajmaind, Juhazren Junaidie, \\ Zulkiflee Haron ${ }^{f}$, Mohd Fauzi Abu Hussing \\ ${ }^{a, b}$ Academy of Islamic Civilization, Faculty of Science Social and Humanities, Universiti
} Teknologi Malaysia, Skudai, Malaysia, c,g Center of Research for Fiqh Science and Technology (CFiRST), Ibnu Sina Institute, Universiti Teknologi Malaysia, Skudai, Malaysia

Corresponding Author: naquiah2@live.utm.my

\begin{abstract}
Active learning through student-centered activity has a significant impact on learning as well as the mastery of the students. The implementation of student-centered activity blended with elements of active learning is among the foundation that forms the 21st century education. However, its implementation is often underestimated due to constraints faced by teachers. This article discusses the elements of active learning within student-centered activity implemented by Islamic Education teachers in primary schools applying the concept of 21st century learning in the process of teaching and learning. This study adopted the qualitative method conducted on seven teachers of Islamic Education primary school in the state of Melaka. In-depth interviews, observations and document analysis were performed for this study and the data were analyzed using NVivo 12.0. The finding indicated that there are six elements of active learning in the activities of student-centered learning that was implemented by the Islamic Education primary school teachers in the state of Melaka. All of the elements involved had demonstrated a pattern, in which all students are involved in the activities, all students perform their own activities, students learn from the activities, varied activities according to the level of students, several sets of activities in a single teaching session and edutainment activities. This study generally suggests a method that could serve as a guideline for teachers to carry out active learning through the student-centered activity in order to realize the concept of 21st century learning in the teaching and learning process. Keywords: Active Learning, Learning Activities, Student-Centered, Education Teacher Islam, PAK21
\end{abstract}




\section{Introduction}

Education is the benchmark for the level of civilization and quality of a country throughout the history of human civilization. In line with the development of world-class education in the 21st century, Malaysia also joined the bandwagon to enhance the quality of the education system as a mean to achieve the country's aspirations. A number of transformational and renewal efforts were done in order to ensure the quality of national education in the best tier and increase in tandem with the world education development as a preparation to face the competition globally. The Ministry of Education Malaysia has made an aggressive transformation by remodeling the national education curriculum to be in line with the demands of education in the 21st century. Basically, the concept of education in the 21st century (PAK21) requires us to switch from the conventional teaching and learning to an approach which is more concerned towards student-centered such as active learning among students. In addition, 21st century learning (PAK21) emphasizes on learning collaboratively, not solely confined to the reception of knowledge but also emphasizing the aspects of skill, practical and hands-on, as well as the concept of learning that is not limited only to physical classroom learning. Thus, students should be equipped with the learning skills focusing on critical thinking, effective communication, problem solving, inventive thinking, digital age literacy, metacognitive skills and high productivity to enable them to compete and address challenges on the international stage (Nurul et al., 2015). In order to achieve this, the Ministry of Education Malaysia has decided to inculcate elements of 21st century skills in all subjects taught at both primary and secondary levels, including Islamic Education.

\section{The Concept of active Learning through Student-centered Activity}

Active learning is a response or active response from students when undergoing the process of learning. Through active learning, students are fully engaged in the learning process (Siti, 2015), giving positive responses as well as actively participating in implementing the given activities. According to Demirci (2017), students who undergo active learning have the opportunity to build knowledge emphasizing on particular aspects of skills such as analytical thinking, problem solving and meta-cognitive activity, which could expand their thinking ability. Therefore, in the context of Islamic Education teachers, their role and wisdom to provide the elements of active learning towards students is crucial, and in line with the concept of 21st century learning.

Active learning can be achieved through the implementation of student-centered activities facilitated by teachers during the teaching and learning process. In fact, the main principle which is said to be the basic to the concept of 21st century learning is the implementation of student-centered learning (Bulletin of Displacement, 2015). Student-centered learning activities are the transformation from conventional teaching in which teachers are dominant while the students are passive recipients, towards empowering the role of students as the main movers in the learning process. Student-centered learning is also defined as an approach that replaces traditional knowledge delivery models to the use of new approaches in teaching and learning, more structured guidance, and curricula that have a clearer focus on student achievement (Gover et al., 2019). This approach also drives towards producing high-quality, flexible and molded students who prioritize individualized learning patterns in line with the concept of 21st century learning. 
The implementation of student-centered activities also ensures active and comprehensive involvement of students which acts as a machine that generates the learning process. Student centralization means that emphasis is given towards the student's involvement in collaboration, critical thinking, problem solving and self-learning to produce active learning, so that students can apply them in real life. According to Nornizam (2018), the concept of student-centered learning can be regarded as the element of reliance on active learning patterns rather than passive learning. Meanwhile, Oinam (2017) had suggest several other elements such as emphasizing critical and analytical thinking as well as emphasizing student understanding, enhancing the value of responsibility and accountability in students, empowering student autonomy, and reflecting the teaching and learning process on both the teachers and students.

Although students have already been given the power of autonomy in 21st century learning, there are still roles for teachers during the teaching and learning process. It is observed that the role of teachers in the 21st century learning is no longer absolutely dominant, or constantly acts as the sole character in the process of knowledge transfer to students during the teaching process. However, the role of teachers in the 21st century education has been facelifted to becoming a facilitator who assists students throughout the learning process. Teachers are facilitators in the context of 21st century learning (Siti, 2015; Alizah and Zamri, 2016; Faizah, 2017) whose role is to help and guide students to gain knowledge and to master skills in a student-centered learning. According to Shanta and Jamalul (2019), in the 21st century teaching, teachers also play a role to help students self-assess their mastery capability as well as strengthen the transferring of knowledge by using effective communication in a comfortable learning environment. In other words, teachers will function as facilitators to create active learning through student-centered activities conducted to ensure the concept of 21st century learning can be brought to reality.

The role of the teacher as a facilitator also means that learning and the process of transferring knowledge to students takes place through 'learning by doing'. Based on the constructivist learning theory, students build their knowledge from the learning activities performed (Alizah \& Zamri, 2016). For primary school students, the construction of knowledge is easier to happen through entertainment-based learning. Entertainment-based learning or edutainment reduces seriousness in the atmosphere of learning (Wan et al., 2015) and is a form of student-centered learning that trains students to act actively and independently build knowledge and seek information (Melvina et al., 2018). The construction of knowledge from student-centered activities through the concept of 'learning by doing' and edutainment promotes active learning among students and in turn, establishing the concept of 21st century learning.

In general, student-centered activities provide an advantage in improving the quality of teaching among teachers as well as the quality of learning among students (Warming \& Frydensberg, 2017). One of the advantages of student-centered activities is being able to attract students to get along the learning process. It was stated by Abdull et al (2016) in their study that students have shown a deep interest in the teaching process based on their positive response and active involvement while participating in student-centered learning activities. Naquiah (2019) found that the student-centered approach had helped to increase students' understanding towards the content of the lesson as well as to facilitate the process of 
imparting knowledge from teachers to students. The students' will continuously record knowledge and information until the activity is completed, and will be stored permanently in their memory (Siti and Hafizhah, 2020).

However, teachers also face various constraints to create active learning through these student-centered learning activities. Undoubtedly, teachers will need to face a challenging journey to come out with the teaching and learning process that truly conforms to the concept of 21st century learning. The diversity of cognitive levels, interests, prior knowledge and learning styles within a group of students in a classroom is seen as a major challenge for the implementation of student-centered learning activities. Teachers also face difficulties to plan and implement appropriate student-centered activities, while fulfilling the diversed needs and levels of students, which would further hamper teachers' efforts to create active learning among students. Planning and implementing separate activities for each student with different learning styles and cognitive levels is not an easy task at all, plus it gets tougher when there is a large number of students in a class. According to Norazlin and Siti (2019), teachers often face difficulties in providing learning materials in large quantities and lack of ideas as well as being less creative in providing materials for students in different classes. This form of difficulty is the biggest challenge in the implementation of student-centered activities in 21st century learning skills (Nur and Noor, 2020).

\section{Objectives of Study}

The objective of study is to examine the elements of active learning implemented through student-centered activities in the teaching and learning process of Islamic Education teachers in primary schools.

\section{Methodology of Study}

Methodology of study is the most basic foundation and determines the quality of a study or research conducted. Aspects that will be emphasized for the methodology of this study are the study's approach, the study's design and the study's sample. According to David (2018), the importance of research methodology cannot be denied because of its role as an entity that drives researchers to determine the most suitable design to be used in the research conducted. For this study, the qualitative descriptive approach was selected and used to describe the phenomena that occur. This study was conducted in several different places, therefore, the multiple case study method was applied in this study.

The state of Melaka was selected as the study location and the Islamic Education primary school teachers were the subject population for this study. This study also uses purposive sampling technique for the process of selecting the study sample. The study sample consists of seven Islamic Education primary school teachers who have been proposed by the Islamic Education Sector, Melaka State Education Department based on the criteria set by the researcher. The selection of this sampling technique coincides with the statement of Chua (2014) and Merriam and Tisdell (2016) that purposive sampling has been widely used in qualitative research to help identify the characteristics of respondents that researchers wanted to be in line with the goals of their study.

The main data collection for this study was carried out through in-depth interviews. These key data are then enriched and reinforced with findings from the observation data and the 
document analysis. Data collection through observation and document analysis methods are also required to be triangulated with the interview data which serves as the main data to ensure its reliability and validity. Based on Patton (2015), the value of reliability and validity of a data will be higher when more data is triangulated by the researchers.

The analysis process for the data that has been collected is implemented through several stages. The process of copying the data into textual form is the first step before analysing the interview data, the observation and the analysis of this document. The transcribed data was then analyzed through several stages using NVivo version 12 software. The first stage in the qualitative data analysis process is the coding process and is followed by the categorization process before the themes are produced. This process coincides with the steps suggested by Miles (2014) that the process of analysis for qualitative data typically involves coding and categorization of data to produce themes. The patterns formed from the resulting themes are then translated into tree diagrams to clarify the findings of the study.

\section{Analysis of Study Findings}

Data obtained through in-depth interviews, observations and document analysis were analyzed thematically using NVivo 12.0 software. A study sample consisting of seven Islamic Education teachers were labeled as GPIS1 to GPIS7 for this study. GPI represents 'Islamic Education Teacher', while $S$ is 'school' and numbers 1 to 7 represent the number of schools. The results show that there are six elements of active learning in student-centered activities implemented by the Islamic Education teachers (GPI) in primary schools. Elements of active learning in GPIS1-GPIS7 student-centered activities are as shown in Table 1.1.

Table 1.1 Elements of Active Learning in Student-Centered Activities GPIS1-GPIS7

\begin{tabular}{c|l|c|c|c|c|c|c|c}
\hline No & \multicolumn{1}{|c|}{ Elements of Active Learning } & S1 & S2 & S3 & S4 & S5 & S6 & S7 \\
\hline 1 & All students are involved in the activity & X & X & X & X & X & X & X \\
\hline 2 & $\begin{array}{l}\text { All students carry out their own } \\
\text { activities }\end{array}$ & X & X & X & X & X & X & X \\
\hline 3 & Students learn from activities & X & X & X & X & X & X & X \\
\hline 4 & $\begin{array}{l}\text { Activities vary according to student } \\
\text { level }\end{array}$ & X & X & X & X & X & X & X \\
\hline 5 & $\begin{array}{l}\text { Several sets of activities in one } \\
\text { learning session }\end{array}$ & X & X & X & X & X & X & X \\
\hline 6 & Entertainment-based activities & X & X & X & X & X & X & X \\
\hline
\end{tabular}

\section{All Students are Involved in the Activity}

The aspect of 'all students involved in activities' is the highest active learning element in student-centered activities implemented by GPIS1-GPIS7 and has reached the pattern level. This aspect was confirmed by all GPIS1-GPIS7 based on data obtained from the analysis through in-depth interview (coded as TB) method (TBGPIS1, 2018: 656; TBGPIS2, 2018: 662; TBGPIS3, 2018: 558; TBGPIS4, 2018: 1131; TBGPIS5, 2018: 378; TBGPIS6, 2018: 439; TBGPIS7, 2018: 659). The aspect of 'all students involved in activities' was also found in all observational data (coded as P) on the GPIS1-GPIS7 teaching and learning sessions (PGPIS1, 2018: 87; PGPIS2, 2018: 532; PGPIS3, 2018: 547; PGPIS4, 2018: 140; PGPIS5, 2018 : 532; PGPIS6, 2018: 179; PGPIS7, 2018: 203) and are also found in the document data (coded as AD) (ADGPIS1, 2018: 117; ADGPIS2, 2018: 93; ADGPIS3, 2018: 104; ADGPIS4, 2018: 66; ADGPIS5, 2018: 81; ADGPIS6, 2018: 61; ADGPIS7, 2018: 84) which were sought through the analysis of their Daily 
Lesson Plan documents. Examples of active learning elements through the aspect of 'all students are involved in activities' as stated by GPIS4 in its interview are:

"PAK21 is a student-centred approach, whereby I let all the students involved in these activities, with no exclusion.."

(TBGPIS4, 2018: 1131)

The measures that involved all students in learning activities are identified to have successfully promote active learning among students and in line with the concept of 21st century learning, but GPI also admitted facing several constraints during implementation (TBGPIS1, 2018: 394; TBGPIS2, 2018: 948; TBGPIS4, 2018: 1149; TBGPIS6, 2018: 457; TBGPIS7, 2018: 671). The huge number of students in a classroom is one of the constraints that need to be faced in an activity when all of them need to participate. GPI faced difficulties in ensuring that the learning process runs in a controlled manner when activities were performed simultaneously by all students, apart from limited and insufficient teaching aids for the use of all students (TBGPIS2, 2018: 948; TBGPIS3, 2018: 1036; TBGPIS4, 2018: 1158; TBGPIS7, 2018: 702). However, GPI successfully addressed these problems by performing collaborative learning through implementation of activities in groups. The discussion that stated to this matter based on excerpted from interviews from GPIS2:

"It's not easy to carry out activities that all students are able to do simultaneously, it's hard to control them..there are activities that I assigned them in groups, or letting them take turns to do and using aids".

(TBGPIS2, 2018: 948)

\section{All Students do their Own Activities}

Achieving the pattern level on the aspect of 'all students do their own activities' is found to be the second highest element of active learning in student-centered activities. This aspect was found in all GPIS1-GPIS7 interviews and observation analysis data (TBGPIS1, 2018: 658; TBGPIS2, 2018: 825; TBGPIS3, 2018: 2068; TBGPIS4, 2018: 537; TBGPIS5, 2018: 1291; TBGPIS6, 2018: 442 ; TBGPIS7, 2018: 327; PGPIS1, 2018: 193; PGPIS2, 2018: 162; PGPIS3, 2018: 507; PGPIS4, 2018: 212; PGPIS5, 2018: 532; PGPIS6, 2018: 126; PGPIS7, 2018: 304) as well as the document analysis sought through the writing of their Daily Lesson Plans (ADGPIS1, 2018: 117; ADGPIS2, 2018: 93; ADGPIS3, 2018: 104; ADGPIS4, 2018: 66; ADGPIS5, 2018: 81; ADGPIS5, 2018: 61; ADGPIS5, 2018: 84). This aspect of 'all students doing their own activities' was agreed to have been implemented by all GPIS1-GPIS7 during the teaching and learning sessions they conducted.

For example, this aspect has been stated by GPIS3 in the interview:

"All learning activities were run by students, that's how i implement PAK21.. for example, all students will participate individually in the bowling sport..students will throw the ball themselves to drop down the pins.."

(TBGPIS3, 2018: 2063)

GPI acknowledged that the emphasis on the implementation of self-directed activities is to ensure active learning among students in line with the concept of 21st century learning (TBGPIS2, 2018: 1075; TBGPIS5, 2018: 824; TBGPIS6, 2018: 591). Students are trained to carry out their own activities and play an active role in the learning process according to the instructions given by their teacher. The role of the teacher in the teaching process is only as 
a facilitator who provides guidance throughout the activities carried out by the students (TBGPIS3, 2018: 495; TBGPIS4, 2018: 839; TBGPIS5, 2018: 1120; TBGPIS7, 2018: 322). Since the learning activities need to be done individually by each student, GPI also ensures that each planned activity is appropriate according to their abilities and level of mastery (TBGPIS1, 2018: 957; TBGPIS3, 2018: 715; TBGPIS7, 2018: 324). This has been stated in the excerpt of the GPIS7 interview:

"I encourgaed students to carry out the activity by themselves and I only hold the character as a facilitator due to the concept of PAK21.. but I'll make sure that all students are able to complete the activity regardless of their level."

(TBGPIS7, 2018: 324)

\section{Students Learn from Activities}

The 'students learn from activities' aspect also achieved the pattern level and is the third highest active learning element in the student-centered activities implemented by GPIS1GPIS7. Based on the data collected from the interviews, all GPIS1-GPIS7 admitted that they had implemented active learning by ensuring that students learn and acquire knowledge from the activities performed by the students themselves (TBGPIS1, 2018: 656; TBGPIS2, 2018: 546; TBGPIS3, 2018: 554; TBGPIS4, 2018: 1129; TBGPIS5, 2018: 378; TBGPIS6, 2018: 655; TBGPIS7, 2018: 660). The aspect of 'students learning from activities' was also found in the data from the GPIS1-GPIS7 observational analysis (PGPIS1, 2018: 193; PGPIS2, 2018: 161; PGPIS3, 2018 : 547; PGPIS4, 2018: 212; PGPIS5, 2018: 532; PGPIS6, 2018: 107; PGPIS7, 2018: 268). This aspect of 'students learn from activities' can be seen through the statement of GPIS5 in its interview:

"While teaching, I will plan activities so that students gain knowledge directly from

the activity .. I'll make sure the students do so, that he can learn from the activities he did".

(TBGPIS5, 2018: 1256)

GPI suggested that in order to master a skill, it is more effective when the students perform the activity themselves which conforms to the concept of the 21st century learning (TBGPIS1, 2018: 714; TBGPIS2, 2018: 493; TBGPIS4, 2018: 2251; TBGPIS7, 2018: 685). The delivery of knowledge will also occur more easily due to the knowledge and skills taught will be maximally absorbed by the students (TBGPIS2, 2018: 729; TBGPIS4, 2018: 1129). Apart from that, the absorption of knowledge occurs optimally when students learn and acquire knowledge directly from the activities they carried out. For example, this has been stated by GPIS4 in its interview:

"In order to ensure students learn a set of skills, students must do the activities in accordance with PAK21 which emphasizes hands-on learning..students find it difficult to understand if they only listen to the teacher's explanation..but when they do, then only students can master the skills to the maximum.."

(TBGPIS4, 2018: 2251)

\section{Activities Vary According to Student Level}

The active learning element in teaching and learning implemented by GPIS1-GPIS7 also covers the aspect of 'different activities according to student level'. The implementation of 'different activities according to student level' is also an aspect that reaches the level of pattern and is admittedly implemented by all GPIS1-GPIS7 in their teaching. This aspect was found in all the 
interview data as well as the data from the observations made on GPIS1-GPIS7 teaching sessions (TBGPIS1, 2018: 670; TBGPIS2, 2018: 2073; TBGPIS3, 2018: 101; TBGPIS4, 2018: 282; TBGPIS5, 2018: 225; TBGPIS6, 2018: 2086; TBGPIS7, 2018: 1282; PGPIS1, 2018: 210; PGPIS2, 2018: 341; PGPIS3, 2018: 216; PGPIS4, 2018: 140; PGPIS5, 2018: 321; PGPIS6, 2018: 388; PGPIS7, 2018: 353) and also the document analysis (ADGPIS1, 2018: 117; ADGPIS2, 2018: 93; ADGPIS3, 2018: 104; ADGPIS4, 2018: 66; ADGPIS5, 2018: 81; ADGPIS5, 2018: 61; ADGPIS5, 2018: 84). An example of this aspect of 'different activities according to student level' is based on an interview excerpt from GPIS6:

"I manage various types of activities..based on different abilities of the student, their abilities are individually differ from the other.. Thus, I assigned different activities separately."

(TBGPIS6, 2018: 683)

GPIS1-GPIS7 took into account the level of ability of each student while performing learning activities. According to them, the learning activities are designed according to the suitability and ability of students of various levels (TBGPIS2, 2018: 258; TBGPIS3, 2018: 513; TBGPIS6, 2018: 740; TBGPIS7, 2018: 337). Lower level students are exposed to light activities such as singing and games, while activities of higher order thinking skills (HOTs) are assigned on high level students (TBGPIS1, 2018: 427; TBGPIS2, 2018: 2073; TBGPIS5, 2018: 506; TBGPIS7, 2018: 972). The following is an example of an interview excerpt that highlighted on this:

"I assigned activities in accordance of the student level..I focused more on drills, play games or singing for the weak student.. while higher order thinking skills for the smart class students"

(TBGPIS2, 2018: 2073)

\section{Several Sets of Activities in one Learning Session}

The analysis of interviews and observations show that the active learning element in the student-centered activities implemented by GPIS1-GPIS7 also includes the implementation aspect of 'several sets of activities in one learning session'. GPIS1-GPIS7 acknowledged that they conducted at least three activities for each teaching and learning session (TBGPIS1, 2018: 680; TBGPIS2, 2018: 2068; TBGPIS3, 2018: 2037; TBGPIS4, 2018: 518; TBGPIS5, 2018: 391; TBGPIS6, 2018: 2085; TBGPIS7, 2018: 390; PGPIS1, 2018: 227; PGPIS2, 2018: 341; PGPIS3, 2018: 335; PGPIS4, 2018: 264; PGPIS5, 2018: 321; PGPIS6, 2018: 388; PGPIS7, 2018: 356). This aspect was also found in the data obtained from the document analysis in the writing of their Daily Teaching Plan (RPH) (ADGPIS1, 2018: 117; ADGPIS2, 2018: 93; ADGPIS3, 2018: 104; ADGPIS4, 2018: 66; ADGPIS5, 2018: 81; ADGPIS5, 2018: 61; ADGPIS5, 2018: 84). The implementation of 'several sets of activities in one learning session' was recorded from GPIS2 in the interview:

"I'll do three to four different activities if 30 minutes of time were given to me... different induction sets of activities, different teaching methods applied for each set."

(TBGPIS2, 2018: 2068)

The rationale behind the implementation of 'several sets of activities in one learning session' is due to the diversity of students' levels in a classroom (TBGPIS1, 2018: 699; TBGPIS2, 2018: 2093; TBGPIS4, 524: 793; TBGPIS5, 2018: 397; TBGPIS6, 2018: 438). Several activities planned had made it easier for students to understand a knowledge imparted when suited to their 
level of ability (TBGPIS2, 2018: 2023; TBGPIS4, 2018: 797; TBGPIS5, 2018: 415). This can be observed through the statement in the GPIS4 interview:

"The reason I arranged multiple activities in one class because there are different levels of student, the activities cannot be for one level only..it has to be varied..for example, you can't just focus on reading, you must also do some spelling or writing or coloring activities.."

(TBGPIS4, 2018: 793)

\section{Entertainment-based Activities}

'Entertainment-based activities' are the last aspect of the active learning element in studentcentered activities implemented by GPIS1-GPIS7. Despite being in the last position but this aspect still achieves its pattern level. This aspect of 'entertainment-based activities' was agreed and acknowledged upon by all GPIS1-GPIS7 to be implemented in their teaching lesson (TBGPIS1, 2018: 694; TBGPIS2, 2018: 590; TBGPIS3, 2018: 103; TBGPIS4, 2018: 944; TBGPIS5, 2018: 400; TBGPIS6, 2018: 485; TBGPIS7, 2018: 379). However, observation data for this aspect of 'entertainment-based activities' were only found on GPIS2-GPIS7 (PGPIS2, 2018: 294; PGPIS3, 2018: 476; PGPIS4, 2018: 481; PGPIS5, 2018: 493; PGPIS6, 2018: 193; PGPIS7, 2018: 624). Although this aspect was stated in the interview session, there was no data found from the observation of GPIS1 during the teaching session. An evidence from the interviews that show this aspect of 'entertainment-type activities' is:

"My entertaining educational activities are singing, games..sometimes I also did some poems, but I usually play songs that the kids like"

(TBGPIS5, 2018: 400)

According to the GPI, 'entertainment-based activities' are focused more on lower level or underprivileged students (TBGPIS3, 2018: 121; TBGPIS5, 2018: 514; TBGPIS6, 2018: 490; TBGPIS7, 2018: 353). Activities that were carried out are singing and games that are able to entertain the students but still contain the learning elements in them. GPI implements 'entertainment-based activities' on weaker students as a way to attract their interest towards learning and to facilitate the process of knowledge transferring (TBGPIS1, 2018: 716; TBGPIS3, 2018: 125; TBGPIS4, 2018: 957; TBGPIS6, 2018: 490; TBGPIS7, 2018: 353). For example, this has been stated in the GPIS7 interview:

"I also inserted entertainment in the form of games for students in weak classes, indirectly attracting students' interest .. and easier to understand compared to just hear my explanation.."

(TBGPIS7, 2018: 353)

\section{Discussion}

Referring to the results of the study, there are six aspects of active learning elements in student-centered activities that have been implemented by the Islamic Education teachers (GPI) in the teaching and learning process. The elements are (i) all students are involved in the activity, (ii) all students do the activity themselves, (iii) students learn from the activity, (iv) different activities according to the level of students, (v) several sets of activities in one teaching session and (vi) entertainment-based activities. All of these elements have achieved the pattern level and were found in the data from the interview of all the GPIS1-GPIS7 study participants. 
The aspect of 'all students are involved in activities' was the first active learning element found in student-centered activities implemented by the Islamic Education teachers in this study. These findings explain that the main feature of active learning is the existence of a holistic student engagement during the implementation of the student-centered activities. Teachers managed to make all students engaged in these activities which resulted in active learning to promote 21st century learning lessons that emphasizes the concept of studentcentered learning. These findings are consistent with the study of Abdul et al (2016) stated that students who are actively involved throughout the course of student-centered activities are resulting from the role played by the teachers involving all students in the teaching and learning process. Meanwhile, Shanta and Jamalul (2019) stated that the characteristics of 21st century learning is the change from one-way learning to student-centered learning that encourages students to be actively involved in learning activities.

However, it is not an easy task to ensure all students involved in an activity at one time. Teachers facing difficulties to ensure the smoothness of the student-centered learning activities. Huge number of students makes it difficult for teachers to sustain control of the students in class. Teachers are also facing time and financial constraints to provide adequate learning materials for the use of all students at the same time. The difficulty of teachers to provide learning materials in sufficient quantity was also stated by Norazlin and Siti (2019) in their study, while Aqilah and Dayana (2020) also acknowledged that these constraints become barriers in implementing student-centered learning activities.

Active learning also will not happen without activities that are performed entirely by students. Therefore, the elements of active learning through student-centered activities for this study also covers the aspect of 'all students do their own activities'. This aspect illustrates that the teaching and learning process is dominated by students who are able to carry out the activities on their own based on the instructions given by the teacher. Based on Siti's (2019) study, student-centered learning that conforms to the concept of 21st century learning which has been done in an active and interactive manner. While the teacher acts as a facilitator who helps and guides students to carry out activities. Teachers give instructions, show and guide them through steps to carry out activities planned. The Ministry of Education Malaysia (2013) and the study of Shanta and Jamalul (2019); Hanim and Nurol (2017); Siti (2015) supported that the role of teachers are to monitor and guide students to promote active learning environment through student-centered activities.

This active self-learning has contributed to the construction of knowledge among students that sticks to the concept of 21st century learning. The gaining and the construction of knowledge show its result when 'students learn from activities' performed in studentcentered learning activity. The concept of learning by doing, creates meaningful learning lessons because students were stimulated to think critically and build their own knowledge through it (Nur and Faridah, 2017). Based on the study of Alizah and Zamri (2016), studentcentered learning activities support the theory of constructivist learning which requires students to build their own knowledge independently through the activities they carried out. Students' knowledge is built by exploring knowledge and maintaining high curiosity in search of answers to a problem and able to come to a conclusion from activities carried out with the guidance of their teacher. The learning and construction of students' knowledge from these activities potentially promotes active learning that is in line with 21st century learning. 
In order to ensure the successfulness of an active learning in student-centered activities, the diversity of the student level should be taken care of and should be given more attention by the Islamic Education teachers as found through this study. Thus, the implementation of 'different activities according to the level of students' also need to be taken into account while they carry out the teaching and learning process. It was found that the teachers are capable in designing student-centered learning activities according to the suitability of the students' level of thinking, abilities and interests. A more relaxed and non-burdensome activities are given to lower level students according to their level of ability and thinking, such as games and singing activities. This finding coincides with the study of Safiek (2019) who stressed the importance of teachers acting accordingly towards different level ability of students to avoid misinterpreting and misunderstanding of the knowledge in an activity. Higher order thinking skills (HOTs) need to be stressed more on students who are identified as having a high cognitive level in order to comply with the concept of 21st century learning. The application of HOTs in learning activities according to the level of ability of students was also stated in the study of Marzni (2018) which emphasizes the need for the teachers to study and evaluate activities based on HOTs that are appropriate to the level and acceptance of students.

The diversity of student levels also shows the need of various different activities within an active learning session. The diversity of student levels also requires teachers to create various learning activities in accordance with the students' level. Therefore, the implementation of 'several activities in a set of learning' is also one of the active learning elements contained in student-centered learning activities implemented by the Islamic Education teachers. These findings coincide with the study of Rosni et al (2020) who found that teachers also carried out a variety of different activities such as reading, watching videos, discussions and analyzing texts in one learning session. The implementation of several activities in a set of learning is to ensure that the students from various levels are able to understand and master the content of a lesson according to the suitability of the activities based on their respective cognitive levels. According to Dicken and Tajul (2017), the need for teachers to implement activities that potentially stimulate their interest and provide understanding to students is very important to create an active learning environment.

'Activities in the form of entertainment education' is also another aspect of student-centered activities in the active learning element implemented by the Islamic Education teachers. Learning activities such as singing and games are elements of entertainment that were chosen by teachers to be applied onto students with lower ability level. Elements of singing and games are applied to make it easier for students to understand the content of a lesson and create a more relaxed and fun learning environment. These findings support the results of the study of Nur (2019) who found that the method of singing-based entertainment has helped students to increase their motivation during the learning process. Through entertaining educational activities such as games, students also have the opportunity to learn without any sense of compulsion and to assist in the development of the students' brain cells that will increase the ability to capture information to the maximum (Siti and Hafizhah, 2020).

\section{Conclusion}

Teachers are the main agent that played a huge role in building the concept of active learning among students. The extent to which student-centered learning activities are able to promote active learning is entirely dependent on the skills, wisdom and competence of the teachers 
while handling the teaching and learning process. The application of active learning elements through student-centered activities which was found in this study are the involvement of all students in activities, the application of entertainment-based activities, the implementation of several sets of activities in a learning session according to students' cognitive level, and the application of self-learning concepts for students to build knowledge can be used as guidelines for the benefit of all teachers in promoting active learning environment. Teachers should be more proactive, creative to fully utilise existing skills and be one step ahead in addressing whatever constraints and problems faced to ensure that the concept of 21st century learning can be successfully achieved. The reality of education today sees that the construction and preparation of future generations in the 21st century rests on the shoulders of every teacher who are the main pillars of the national education system. The successfulness of building a generation in line with the characteristics of the 21st century is also a reflection of the country's academic achievement and progress in the eyes of the world.

\section{Acknowledgements}

This work was supported by a Fundamental Research Grant Scheme (FRGS) grant (FRGS/1/2020/SS03/UTM/02/1, Cost Center No. R.J130000.7853.5F386) from the Ministry of Higher Education, Malaysia. The authors would like to thank all the individuals who have contributed in this paper.

\section{References}

Abdull, S. S., Mohd, I. G., Nurahimah, M. Y., \& Mohd, I. A. (2016). Amalan Pedagogi Berpusatkan Pelajar dan Masalah Yang Dihadapi Guru-Guru Pelatih Program Pensiswazahan Guru untuk Mengamalkan Pedagogi Berpusatkan Pelajar Semasa Praktikum. Proceeding of ICECRS, 1 (2016), 599-608.

Alizah, L., \& Zamri, M. (2016). Pelaksanaan Aktiviti Pembelajaran Berasaskan Masalah dalam Proses Pengajaran dan Pembelajaran Bahasa Melayu. PENDETA - Jurnal Bahasa dan Sastera Melayu, 98-117.

Buletin Anjakan. (2015). Ciri-Ciri Guru Abad 21. Pelan Pembangunan Pendidikan Malaysia 2013-2025, p.2.

Chua, Y. P. (2014). Kaedah penyelidikan. Kuala Lumpur: McGraw-Hill (Malaysia) Sdn Bhd.

David, S. (2018). Doing qualitative research: A practical handbook. 5th ed. London: Sage Publications.

Demirci, C. (2017). The Effect of Active Learning Approach on Attitudes of 7th Grade Students. International Journal of Instruction, 10(4), 129-144.

Dicken, K., \& Tajul, A. M. (2017). Cabaran Pengajaran Subjek Pendidikan Jasmani di Sekolah Menengah di Malaysia. Journal of Nusantara Studies 2017, 2(2) 53-65.

Faizah, J. (2017). Bahan Bantu Mengajar (BBM) dalam Pengajaran dan Pembelajaran (P\&P) di Sekolah Menengah Kebangsaan (SMK) Daerah Pontian. Tesis Sarjana Pendidikan Teknik dan Vokasional. Universiti Tun Hussein Onn, Malaysia.

Gover, A., Loukkola, T., \& Peterbauer, H. (2019). Report Student-centred learning: approaches to quality assurance. Brussels: European University Association.

Hanim, P., \& Nurol, A. G. (2017). Pelaksanaan Pembelajaran Berpusatkan Pelajar di Jabatan Perdagangan. Projek Ilmiah. Politeknik Merlimau Melaka.

Malaysia Education Ministry. (2013). Pelan Pembangunan Pendidikan Malaysia 2013 - 2025. https://www.moe.gov.my/imagines/dasar-kpm/PPP/Pleminary-BlueprintBM.pdf 
Malaysia Education Ministry. (2015). Modul Kursus Peningkatan Profesionalisme Guru Bahasa Melayu. Putrajaya: Bahagian Pendidikan Guru.

Marzni, M. M. (2018). Penerapan Kemahiran Berfikir Aras Tinggi dalam Pembelajaran dan Pemudahcaraan Penulisan Karangan Argumentatif. Tesis Doktor Falsafah. Universiti Sains Malaysia.

Melvin, C. H. C., Norazah, M. N., \& Jamaludin, B. (2018). Penggunaan Kaedah Didik Hibur melalui Permainan Interaktif dalam Pembelajaran Bahasa Melayu. Prosiding Seminar on TransdisciplinaryEducation 2018, 1-7.

Merriam, S. B., \& Tisdell, E. J. (2016). Qualitative Research: A Guide to Design and Implementation. 4th ed. San Francisco: Jossey-Bass Publishers.

Miles, M. B., Huberman, A. M., \& Saldana, J. (2014). Qualitative Data Analysis A Methods Sourcebook. Los Angeles: SAGE Publications, Inc.

Naquiah, N. (2019). Amalan dan Kompetensi Pengajaran Jawi Guru Pendidikan Islam Sekolah Rendah. Tesis Doktor Falsafah. Universiti Teknologi Malaysia.

Norazlin, M. R., \& Siti, R. A. (2019). Amalan dan Cabaran Pelaksanaan Pembelajaran Abad ke21. Proceedings of the International Conference on Islamic Civilization and Technology Management, 23-24 November 2019, 87-105.

Nornizam, J. (2018). Pembelajaran Abad ke-21 (PAK21) Teras Kemenjadian Pelajar Zaman Revolusi Perindustrian 4.0. The Patriots. https://www.thepatriots.asia/16750-2/ (accessed 1Disember 2020).

Nur, A. I. H. (2019). Penggunaan Kaedah Didik Hibur untuk Pembelajaran Matematik dalam Kalangan Pelajar Sekolah Rendah Taman Sri Rampai. Tesis Sarjana. University of Malaya.

Nur, A. R., \& Noor, D. A. H. (2020). Kesan Pembelajaran Berasaskan Inkuiri dengan Integrasi Video Terhadap Pencapaian Pelajar dalam Pembelajaran Matematik. Innovative Teaching and Learning Journal, 3(2), 42-60.

Nur, A. A., \& Faridah, Y. (2017). Kesediaan Guru Prasekolah dalam Melaksanakan KBAT dalam Pengajaran dan Pembelajaran. Simposium Pendidikan diPeribadikan: Perspektif Risalah An-Nur (SPRiN2017), 147-152.

Nurul, N. S., Noor, H. H., \& Nur, A. A. H. (2015). Matematik dan kemahiran abad ke-21: perspektif pelajar. Jurnal Pendidikan Matematik, 3 (1), 24-36.

Oinam, S. (2017). Student- Centered Approach to Teaching and Learning in Higher Education for Quality Enhancement. IOSR Journal Of Humanities And Social Science (IOSR-JHSS), 22 (6), 27-30.

Patton, M. Q. (2015). Qualitative Research and Evaluation Methods. 4th ed. Thousand Oaks, CA: Sage.

Rosni, S., Aishah, I., \& Wan, A. W. A. (2020). Amalan Guru Cemerlang dalam Pengajaran dan Pembelajaran (PdP) Bahasa dan Sastera Arab Mengikut Strategi Ibnu Khaldun. Asia Pacific Journal of Educators and Education, 35(1), 37-54.

Safiek, M. (2019). Pemupukan Kreativiti Kanak-Kanak: Kajian Kes Amalan Pengajaran Kreativiti di Sebuah Tadika Islam. Attarbawiy: Malaysian Online Journal of Education, 3 (1) (2019), 34-48.

Shanta, G., \& Jamalul, L. A. W. (2019). Tahap Keberkesanan Pelaksanaan Kaedah Bilik Darjah Songsang (Flipped Class) di Sekolah Menengah. Jurnal Penyelidikan Pendidikan Jilid 20, 96-112. 
Siti, A. I., \& Hafizhah, Z. (2020). Penggunaan Kaedah Circle Time Dalam Meningkatkan Kemahiran Membaca Bacaan Mad Asli Dan Mengenal Mad Asli. Journal of Educational Research and Indigeneous Studies. 1 (1), 1-20.

Siti, N. A. I. (2015). Penguasaan Teknik Kemahiran Fasilitator dalam Pelaksanaan Pembelajaran Berpusatkan Pelajar di Universiti Tun Hussein Onn Malaysia. Tesis Sarjana Pendidikan Teknik dan Vokasional. Universiti Tun Hussein Onn, Malaysia.

Siti, S. S. (2019). Konsep Pembelajaran Berasaskan Projek Dalam Aktiviti Pembelajaran Bersepadu Di Kelas Prasekolah. IPG Kampus Tun Hussein Onn. 1-12. https://www.researchgate.net/publication/331673262_

Wan, M. W. I., Mat, A. M. A., Azilawati, R, Wan, M. R. W. I., Normala, R., \& Irm, S. S. (2015). Conceptual Framework of Edutainment Animated Series for Children: A Pious Story. ARPN Journal of Ingeneering and Applied Sciences, 10(3), 1106-1113.

Warming, R., \& Frydensberg, P., 2017, Principal in Own Learning - Student Centred Learning Viewed Through the Eyes of an External Quality Assurance Agency. EQAF Paper. http://bit.ly/2LJ6XFI (accessed 25.11.2020). 